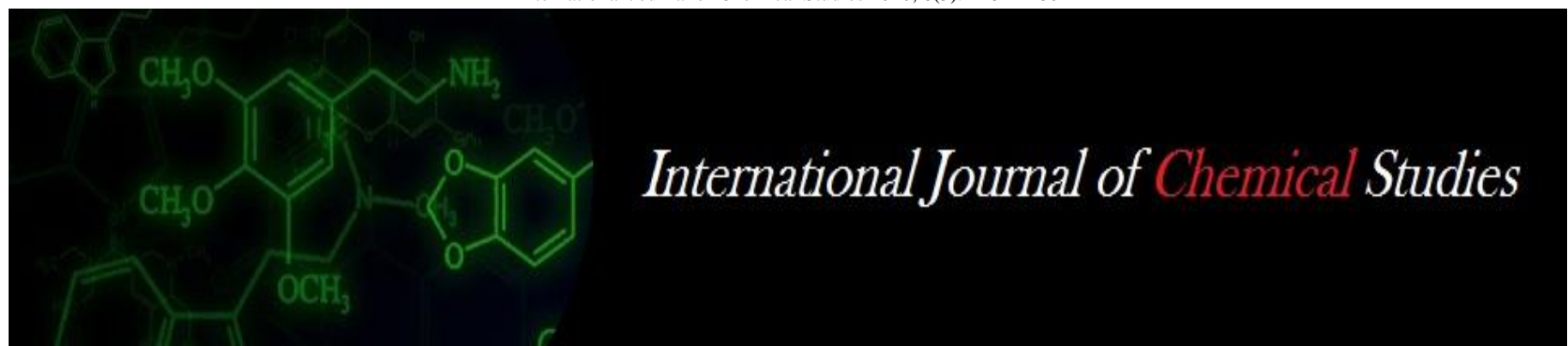

P-ISSN: 2349-8528

E-ISSN: 2321-4902

www.chemijournal.com

IJCS 2020; 8(5): 2282-2286

(C) 2020 IJCS

Received: 29-07-2020

Accepted: 03-09-2020

Shreyasha V Wankhade

M.Sc. Student, Entomology

Section, College of Agriculture,

Nagpur, Maharashtra, India

HR Sawai

Assistant Professor, Entomology

Section, College of Agriculture,

Nagpur, Maharashtra, India

Pranita R Chaure

M.Sc. Student, Department of Soil Science and Agricultural

Chemistry, PGI, Dr. PDKV

Akola, Maharashtra, India

Renuka D Pawar

M.Sc. Student, Entomology Section, College of Agriculture,

Nagpur, Maharashtra, India

Corresponding Author:

Pranita R Chaure

M.Sc. Student, Department of

Soil Science and Agricultural

Chemistry, PGI, Dr. PDKV

Akola, Maharashtra, India

\section{Comparative toxicity of certain insecticides against Chrysoperla Spp. (Neuroptera: chrysopidae) under laboratory conditions}

\author{
Shreyasha V Wankhade, HR Sawai, Pranita R Chaure and Renuka D \\ Pawar
}

DOI: https://doi.org/10.22271/chemi.2020.v8.i5ae.10647

\begin{abstract}
Toxicity of newer insecticides viz., chlorantraniliprole $18.5 \mathrm{SC}$, flubendiamide $20 \mathrm{WG}$, buprofezin 25 SC, lambda cyhalothrin 9.5 + thiamethoxam $12.6 \mathrm{ZC}$, lambda cyhalothrin $5 \mathrm{EC}$, azadirachtin $5 \mathrm{w} / \mathrm{w}$, thiamethoxam $25 \mathrm{WG}$, thiachloprid 21.7 SC were tested against different larval stages of Chrysoperla spp. under laboratory conditions. The observations on percent mortality of $1^{\text {st }}, 2^{\text {nd }}$ and $3^{\text {rd }}$ instar of $C$. spp. larvae were recorded after 24,48 and $72 \mathrm{hrs}$ of application. The results showed that lambda cyhalothrin + thiamethoxam was found toxic to all instars of Chrysopa larvae whereas azadirachtin was found safest insecticide against all instar of Chrysopa larvae at all treatment intervals. Considering ecofreindliness, it can be concluded that insecticides azadirachtin, buprofezin and flubendiamide were found most safer to all instars of $C$. spp. which can be taken successfully in the IPM programmes whereas, lambda cyhalothrin + thiamethoxam was found most harmful to all instars of larvae.
\end{abstract}

Keywords: Chrysoperla spp., mortality, larvae, toxicity, insecticides

\section{Introduction}

Biological control is involvement of parasitoids, predators and pathogens in maintaining other organisms density at a lower average level than would occur in their absence (DeBach, 1965) ${ }^{[4]}$. Bioagent can cause substantial decrease in pest population numbers (Hassell, 1978) ${ }^{[12]}$. In different agro-ecosystem the Green lacewing is an important natural enemy, belonging to family Chrysopidae, order Neuroptera. Green lacewing is a native North American species (Garland, 1985) ${ }^{[8]}$. Chrysoperla carnea is predominant species of green lacewing, having green cylindrical body, transparent wing with light green veins, long filiform antennae, golden eyes and stalked eggs that offer protection from predation (Pedigo, 1989) ${ }^{[24]}$. Larval stage is active predatory stage (Michaud, 2001) ${ }^{[19]}$. Larvae of Chrysoperla carnea is polyphagous, voracious feeder of Cotton aphids, Aphis gossypii Glover; Corn earworm, Helicoverpa zea Boddie (Lingren et al., 1968) ${ }^{[16]}$; Colarado potato beetle, Leptinotarsa decemlineata (Say) (Nordlund et al., 1991) ${ }^{[22]}$.

In agroecosystems, various biocontrol agents are one of the important components of the pest management, which have proved as best alternative over several insecticides (Singh, 2015) ${ }^{[26]}$. The insecticides commonly used to control the pest population have indirect effect on these natural enemies. Constant disturbances to agricultural ecosystem using chemical pesticides upset the natural balance causing pest up surgence (Prema et al., 2016) ${ }^{[25]}$. The impact of synthetic pesticides on the environment, the beneficial arthropods and the human health by exposure to these chemicals are issues of growing concern (Garzon et al., 2015) ${ }^{[9]}$. The need for more selective insecticides was one of the key themes during the evolution of poison free management of insect-pests (Sparks, 2013) ${ }^{[29]}$. The purpose of work reported here was to evaluate the effects of insectcides on larvae of $C$. carnea under laboratory conditions.

\section{Materials and Methods}

Laboratory studies were conducted to find out the toxicity of newer group of insecticides on Chrysoperla sp. (carnea- group) during Kharif 2017-2018. The rearing of the host insect and predator was done under controlled room temperature and relative humidity conditions ranging 
Between $26 \pm 2^{\circ} \mathrm{c}$ and $60 \pm 5 \%$, respectively and commercial formulations of insecticides used for the study were procured from the market. Mass multiplication of Chrysopa was done in the laboratory to obtain healthy culture of the test predator. The initial culture was obtained from the already established culture of Chrysopa in Biocontrol laboratory, Entomology Section College of Agriculture, Nagpur and was further multiplied on the factitious laboratory host, eggs of rice moth. To obtain the eggs of Corcyra cephalonica throughout the experimental period, rearing of rice moth was done in the laboratory and the culture was maintained on sorghum based artificial diet.

Table 1: Treatment details:

\begin{tabular}{|c|c|c|}
\hline Tr. No. & Treatment name & Conc. $(\boldsymbol{\%})$ \\
\hline T1 & Chlorantraniliprole 18.5 SC & 0.005 \\
\hline T2 & Flubendiamide 20 WG & 0.01 \\
\hline T3 & Buprofezin 25 SC & 0.05 \\
\hline T4 & Lambda cyhalothrin 9.5 + thiamethoxam 12.6 ZC & 0.008 \\
\hline T5 & Lambda cyhalothrin 5 EC & 0.003 \\
\hline T6 & Azadirachtin 5 w/W & 0.002 \\
\hline T7 & Thiamethoxam 25 WG & 0.005 \\
\hline T8 & Thiachloprid 21.7 SC & 0.004 \\
\hline T9 & Control (water spray) & - \\
\hline
\end{tabular}

The insecticides were classified in different categories on the bases of per cent mortality of larvae, as suggested by IOBC/WPRS (Sterk et al. 1999) ${ }^{[30]}$ as under:

Harmless (toxicity class 1 ) = less than $30 \%$ mortality, Slightly harmful (toxicity class 2 ) $=30-79 \%$ mortality, Moderately harmful (toxicity class 3 ) $=80-89 \%$ mortality, Harmful (toxicity class 4$)=$ more than $90 \%$ mortality.

\section{Treatment of larvae}

Leaf dip assay was used to treat the larvae, as it more closely to the field exposure. Fresh, medium size and unsprayed leaves of cotton (Gossypium hirsutum) variety Bt- cotton were collected from 60 days old plants. Leaves were cut into same diameter of petri plates. Leaf discs were dipped for 5 seconds into insecticide solutions and in water for control. All treated and control leaf discs were allowed to air dry and placed in Petri plates $(1.25 \mathrm{~cm}$ dia. and $0.75 \mathrm{~cm}$ deep). Water moistened filter paper placed underneath of each leaf disc. The larvae of $1^{\text {st }}, 2^{\text {nd }}$ and $3^{\text {rd }}$ instars were placed in Petri plates separately. Irradiated eggs of Corcyra cephalonica was sprinkled in each Petri plate as a food for larvae. The treated larvae were considered dead when they no longer moved, twitched or when being touched 2-3 times with a brush. Mortality data was recorded at end of each exposed and subsequent instars after 24, 48 and 72 hrs up to pupation.

The mean per cent mortality of larvae in different treatments were calculated by the formula given here under:
Mean per cent mortality of larvae $=\frac{\text { Number of larvae dead }}{\text { Number of larvae released }} \times 100$

\section{Statistical Analysis}

The data on all relevant observation thus obtained were subjected for appropriate statistical analysis, Gomez and Gomez (1984) [10]. The corrected per cent mortalities were transformed to arcsine percentage and subjected to statistical analysis adopting Completely Randomized Design (CRD).

\section{Results and Discussion}

The results obtained from the present investigation as well as relevant discussion have been summarized under following heads:

\section{Effect of various insecticides on per cent mortality of first instar Chrysoperla spp. larvae}

The figures presented in table 2 exhibited that the toxicity of different insecticides against first instar Chrysopa larvae varied significantly after different time intervals and increased significantly with the increase in exposure period from $24 \mathrm{hrs}$ to $72 \mathrm{hrs}$.

The mortality data showed that the safest insecticide was azadirachtin with 26.66 per cent mortality of Chrysopa larvae and differed significantly with control, where as maximum mortality of first instar larvae of Chrysopa was obtained with lambda cyhalothrin + thiamethoxam $(90.00 \%)$ followed by thiamethoxam, lambda cyhalothrin, chlorantraniliprole, thiachloprid, flubendiamide and buprofezin with 86.66, 83.33, $80.00,53.33,36.66$ and 33.33 per cent, respectively up to 72 hrs exposure period. Similar results were also reported by, Aggarwal and Brar (2005) ${ }^{[1]}$ reported that neemazal T/S 1.0\% at $200,400,800 \mathrm{mg} / \mathrm{l}$ caused mortality with $12.33,33.36$ and 45.33 per cent first instar larvae of $C$. carnea. However, Erkilic and Ygnn (1997) ${ }^{[7]}$ and Liu et al. (2000) ${ }^{[17]}$ stated that buprofezin was harmless with very limited detrimental effects on natural enemies and did not affect development of instars and pupae of Chrysoperla rufilabris, respectively. Ullah et al. (2017) ${ }^{[31]}$ observed that flubendiamide caused 43.33 mortality of the $1^{\text {st }}$ instar larvae. Ahmad et al. (2014) ${ }^{[2]}$ and Moens et al. (2011) ${ }^{[20]}$ reported that thiacloprid was safer to natural enemies and larvae of diptran hoverfly, Episyrphus balteaus and predatory mite, N. fallacis in the laboratory conditions, respectively. Hussain et al. (2012) ${ }^{[14]}$ and Huggi and Mallapur (2016) [13] found that chlorantraniliprole as intermediately toxic which caused 72 and 85.00 per cent mortality of larvae of $C$. carnea respectively. Govindaraj et al. (2015) ${ }^{[11]}$ found that lambda cyhalothrin @ $25 \mathrm{~g}$ a.i. ha ${ }^{1}$ causing 83.33 per cent grub mortality. Khuram and Ashfaq (2011) ${ }^{[15]}$ assessed that thiamethoxam (0.12 g/l) caused toxicity to $1^{\text {st }}$ instar larvae of $C$. carnea of about 62.5 per cent mortality under laboratory conditions.

Table 2: Effect of various insecticides on per cent mortality of first instar of Chrysoperla spp. Larvae

\begin{tabular}{|c|c|c|c|c|c|}
\hline \multirow{2}{*}{ Tr. No } & \multirow{2}{*}{ Treatments } & \multirow{2}{*}{ Dose/l. } & \multicolumn{3}{|c|}{$\mathbf{1}^{\text {st }}$ instar larval mortality (\%) } \\
\cline { 5 - 6 } & & & $\mathbf{2 4} \mathbf{~ h r s}$ & $\mathbf{4 8 ~ h r s}$ & $\mathbf{7 2} \mathbf{~ h r s}$ \\
\hline $\mathrm{T}_{1}$ & Chlorantraniliprole 18.5 SC & $0.27 \mathrm{ml}$ & $23.33(28.86)$ & $50.00(45.00)$ & $80.00(63.43)$ \\
\hline $\mathrm{T}_{2}$ & Flubendiamide 20 WG & $0.5 \mathrm{gm}$ & $16.66(24.04)$ & $23.33(28.86)$ & $36.66(37.23)$ \\
\hline $\mathrm{T}_{3}$ & Buprofezin 25 SC & $2 \mathrm{ml}$ & $13.33(21.39)$ & $20.00(26.57)$ & $33.33(35.24)$ \\
\hline $\mathrm{T}_{4}$ & Lambda cyhalothrin 9.5 + thiamethoxam 12.6 ZC & $0.36 \mathrm{ml}$ & $33.33(35.24)$ & $60.00(50.77)$ & $90.00(71.57)$ \\
\hline $\mathrm{T}_{5}$ & Lambda cyhalothrin 5 EC & $0.6 \mathrm{ml}$ & $26.66(31.05)$ & $53.33(46.89)$ & $83.33(65.88)$ \\
\hline $\mathrm{T}_{6}$ & Azadirachtin 5 w/W & $0.4 \mathrm{ml}$ & $10.00(18.43)$ & $16.66(24.04)$ & $26.66(31.05)$ \\
\hline $\mathrm{T}_{7}$ & Thiamethoxam 25 WG & $0.2 \mathrm{gm}$ & $30.00(33.21)$ & $56.66(48.79)$ & $86.66(68.28)$ \\
\hline $\mathrm{T}_{8}$ & Thiachloprid 21.7 SC & $0.18 \mathrm{ml}$ & $20.00(26.57)$ & $40.00(39.23)$ & $53.33(46.89)$ \\
\hline
\end{tabular}




\begin{tabular}{|c|c|c|c|c|c|}
\hline $\mathrm{T}_{9}$ & Control & Water & $0.00(0.00)$ & $0.00(0.00)$ & $0.00(0.00)$ \\
\hline & 'F' test & & Sig. & Sig. & Sig. \\
\hline & SE $(m) \pm$ & & 1.78 & 1.62 & 1.91 \\
\hline & CD at 5\% & & 5.17 & 4.71 & 5.55 \\
\hline
\end{tabular}

(Values in the parenthesis are arc sine transformed)

Effect of various insecticides on per cent mortality of second instar Chrysoperla spp. larvae.

The data contained in Table 3 revealed that the mortality of third instar Chrysopa larvae increased significantly with the increase in exposure period from $24 \mathrm{hrs}$ to $72 \mathrm{hrs}$.

The mortality data showed that the safest insecticide was azadirachtin with 23.33 per cent mortality of Chrysopa larvae and differed significantly with control, where as maximum mortality of first instar larvae of Chrysopa was obtained with lambda cyhalothrin + thiamethoxam $(73.33 \%)$ followed by, lambda cyhalothrin, thiamethoxam, chlorantraniliprole, thiachloprid, flubendiamide and buprofezin with 73.33, 70.00, $56.66,53.33,46.66,33.33$ and 26.66 per cent larval mortality, respectively, up to $72 \mathrm{hrs}$ exposure period.

Table 3: Effect of various insecticides on per cent mortality of second instar Chrysoperla spp. larvae.

\begin{tabular}{|c|c|c|c|c|c|}
\hline \multirow{2}{*}{ Tr. No } & \multirow{2}{*}{ Treatments } & \multirow{2}{*}{ Dose/l } & \multicolumn{3}{|c|}{$2^{\text {nd }}$ instar larval mortality (\%) } \\
\hline & & & 24 hrs & 48 hrs & 72 hrs \\
\hline $\mathrm{T}_{1}$ & Chlorantraniliprole $18.5 \mathrm{SC}$ & $0.27 \mathrm{ml}$ & $23.33(28.86)$ & $36.66(37.23)$ & $53.33(46.89)$ \\
\hline $\mathrm{T}_{2}$ & Flubendiamide $20 \mathrm{WG}$ & $0.5 \mathrm{gm}$ & $16.66(24.04)$ & $26.66(31.05)$ & $33.33(35.24)$ \\
\hline $\mathrm{T}_{3}$ & Buprofezin 25 SC & $2 \mathrm{ml}$ & $13.33(21.39)$ & $23.33(28.86)$ & $26.66(31.05)$ \\
\hline $\mathrm{T}_{4}$ & Lambda cyhalothrin $9.5+$ thiamethoxam $12.6 \mathrm{ZC}$ & $0.36 \mathrm{ml}$ & $33.33(35.24)$ & $50.00(45.00)$ & $73.33(58.89)$ \\
\hline $\mathrm{T}_{5}$ & Lambda cyhalothrin $5 \mathrm{EC}$ & $0.6 \mathrm{ml}$ & $30.00(33.21)$ & $46.66(43.05)$ & $70.00(56.79)$ \\
\hline $\mathrm{T}_{6}$ & Azadirachtin $5 \mathrm{w} / \mathrm{w}$ & $0.4 \mathrm{ml}$ & $10.00(18.43)$ & $16.66(24.04)$ & $23.33(28.86)$ \\
\hline $\mathrm{T}_{7}$ & Thiamethoxam $25 \mathrm{WG}$ & $0.2 \mathrm{gm}$ & $26.66(31.05)$ & $43.33(41.15)$ & $56.66(48.79)$ \\
\hline $\mathrm{T}_{8}$ & Thiachloprid 21.7 SC & $0.18 \mathrm{ml}$ & $20.00(26.57)$ & $33.33(35.24)$ & $46.66(43.05)$ \\
\hline $\mathrm{T}_{9}$ & Control & Water & $0.00(0.00)$ & $0.00(0.00)$ & $0.00(0.00)$ \\
\hline & 'F' test & & Sig. & Sig. & Sig. \\
\hline & $\mathrm{SE}(\mathrm{m}) \pm$ & & 1.78 & 1.90 & 1.82 \\
\hline & $\mathrm{CD}$ at $5 \%$ & & 5.17 & 5.53 & 5.31 \\
\hline
\end{tabular}

(Values in the parenthesis are arc sine transformed)

Similar results were also reported by, Shah et al. (2012) [27] proved neembaan as the safest, showing less than $50 \%$ mortality even at higher doses. Meghannavar and Kambrekar (2016) ${ }^{[18]}$ in their studies observed the toxicity of insecticides to second instar grub of Chrysoperla zastrowi sillemi and classified buprofezin 50 SC @ $0.25 \mathrm{ml} / 1$ as harmless. Hussain et al. (2012) [14] found that flubendiamide and chlorantraniliprole caused 56.00 and 64 per cent mortality of $2^{\text {nd }}$ instar larvae respectively where as, Amarsekare and Shearer (2013) ${ }^{[3]}$ observed that lambda cyhalothrin caused significant mortality to both species of second instar Chrysoperla carnea and Chrysoperla johnsoni with 73.3 and 66.7 per cent mortality at 10 DAT (Days After Treatment). El-Zahi and El-Zahi (2012) [6] found that thiamethoxam caused $42.18 \%$ mortality against second instar larvae of $C$. carnea and Nasreen et al. (2005) [21] also found that thiamethoxam as moderately harmful to $C$. carnea larvae at lower concentration $(\mathrm{C} 1)$ and was toxic at recommended and higher concentrations which is in line with the present studies.

\section{Effect of various insecticides on per cent mortality of third instar Chrysoperla spp. larvae.}

The data contained in Table 4 revealed that the mortality of third instar Chrysopa larvae increased significantly with the increase in exposure period from $24 \mathrm{hrs}$ to $72 \mathrm{hrs}$.

After 72 hrs exposure period, the order of toxicity of tested insecticides viz., lambda cyhalothrin + thiamethoxam, lambda cyhalothrin, chlorantraniliprole, thiamethoxam, thiachloprid, flubendiamide and buprofezin was recorded with 63.33, $46.66,43.33,36.66,33.33,26.66,20.00$ per cent larval mortality, respectively. However, application of azadirachtin was significantly less toxic to the third instar larvae of Chrysopa with 16.66 per cent larval mortality at $72 \mathrm{hrs}$, respectively. Thus, data presented in table 4 showed that as the larvae became larger in size from first to third instar, their tolerance to insecticides also increased.

Table 4: Effect of various insecticides on per cent mortality of third instar Chrysoperla spp. larvae.

\begin{tabular}{|c|c|c|c|c|c|}
\hline \multirow{2}{*}{ Tr. No. } & \multirow{2}{*}{ Treatments } & \multirow{2}{*}{ Dose/lit. } & \multicolumn{3}{|c|}{ 3rd instar larval mortality (\%) } \\
\hline & & & 24 hrs & $48 \mathrm{hrs}$ & $72 \mathrm{hrs}$ \\
\hline $\mathrm{T}_{1}$ & Chlorantraniliprole $18.5 \mathrm{SC}$ & $0.27 \mathrm{ml}$ & $23.33(28.86)$ & $36.66(37.23)$ & $43.33(41.15)$ \\
\hline $\mathrm{T}_{2}$ & Flubendiamide $20 \mathrm{WG}$ & $0.5 \mathrm{gm}$ & $16.66(24.04)$ & $23.33(28.86)$ & $26.66(31.05)$ \\
\hline $\mathrm{T}_{3}$ & Buprofezin 25 SC & $2 \mathrm{ml}$ & 13.33(21.39) & $16.66(24.04)$ & $20.00(26.57)$ \\
\hline $\mathrm{T}_{4}$ & Lambda cyhalothrin $9.5+$ thiamethoxam $12.6 \mathrm{ZC}$ & $0.36 \mathrm{ml}$ & $33.33(35.24)$ & $50.00(45.00)$ & $63.33(52.71)$ \\
\hline $\mathrm{T}_{5}$ & Lambda cyhalothrin 5 EC & $0.6 \mathrm{ml}$ & $30.00(33.21)$ & $40.00(39.23)$ & $46.66(43.05)$ \\
\hline $\mathrm{T}_{6}$ & Azadirachtin $5 \mathrm{w} / \mathrm{w}$ & $0.4 \mathrm{ml}$ & $10.00(18.43)$ & $13.33(21.39)$ & $16.66(24.04)$ \\
\hline $\mathrm{T}_{7}$ & Thiamethoxam $25 \mathrm{WG}$ & $0.2 \mathrm{gm}$ & $26.66(31.05)$ & $33.33(35.24)$ & $36.66(37.23)$ \\
\hline $\mathrm{T}_{8}$ & Thiachloprid 21.7 SC & $0.18 \mathrm{ml}$ & $20.00(26.57)$ & $30.00(33.21)$ & $33.33(35.24)$ \\
\hline $\mathrm{T}_{9}$ & Control & Water & $0.00(0.00)$ & $0.00(0.00)$ & $0.00(0.00)$ \\
\hline & 'F' test & & Sig. & Sig. & Sig. \\
\hline & $\mathrm{SE}(\mathrm{m}) \pm$ & & 1.78 & 1.75 & 1.87 \\
\hline & $\mathrm{CD}$ at $5 \%$ & & 5.17 & 5.09 & 5.45 \\
\hline
\end{tabular}

(Values in the parenthesis are arc sine transformed) 
Similar results were also reported by, Aggarwal and Brar (2005) ${ }^{[1]}$ reported that neemazal T/S $1.0 \%$ at 200, 400800 $\mathrm{mg} / \mathrm{l}$ caused $8.33,10.33$ and 16.86 per cent mortality of third instar larvae of C. carnea. Erkilic and Ygnn (1997) ${ }^{[7]}$ who showed no or very limited detrimental effects on natural enemies, whereas Hussain et al. (2012); Garzon et al. (2015) and Ullah et al. (2017) ${ }^{[14,9,31]}$ reported that flubendiamide and chlorantraniliprole which caused 52.00 and 68 per cent post treatment mortality of $3^{\text {rd }}$ instar larvae and flubendiamide was found safer to 3rd instar larvae causing 6-36 per cent mortality, respectively. Omar et al. (2002) and Devi et al. (2014) ${ }^{[23,5]}$ reported that undesirable effect of thiamethoxam against $C$. carnea which decreased 31.00 and 26.67 per cent $3^{\text {rd }}$ instar larval mortality. Silva et al. (2017) ${ }^{[28]}$ classified lambda cyhalothrin as harmful (Class 4) in toxicity classes which is line with the present findings.

\section{Conclusion}

Considering ecofriendliness, it can be concluded from the present investigation that insecticides azadirachtin, buprofezin and flubendiamide were found most safer to all instars of Chrysoperla spp. which can be taken successfully in the IPM programmes. Where as lambda cyhalothrin + thiamethoxam was found most harmful to all instars of larvae

\section{Acknowledgement}

We highly indebted to Dr. N. D. Parlawar, Associate Dean, College of Agriculture, Nagpur and Professors of Entomology Section, College of Agriculture, Nagpur and Arvind Gakhare, Laboratory Assistant, Biocontrol laboratory, College of Agriculture, Nagpur for their kind help for rearing of Chrysoperla spp.

\section{References}

1. Aggarwal N, Brar DS. Effects of different neem preparations in comparison to synthetic insecticides on the whitefly parasitoid Encarsia sophia (Hymenoptera: Aphelinidae) and the predator Chrysoperla carnea (Neuroptera: Chrysopidae) on cotton under laboratory conditions. J Pest Sci. 2005; 79(4):201-207.

2. Ahmed S, Nisar MS, Shakir MM, Imran M, Iqbal K. Comparative efficacy of some neonicotinoids and traditional insecticides on sucking insect pests and their natural enemies on Bt-121 cotton. Journal of Animal \& Plant Sciences. 2014; 24(2):660-663.

3. Amarasekare KG, Shearer PW. Comparing Effects of Insecticides on Two Green Lacewings Species, Chrysoperla johnsoni and Chrysoperla carnea (Neuroptera: Chrysopidae). J Economic Entomology. 2013; 106(3):1126-1133.

4. DeBach P. Some biological and ecological phenomena associate with colonizing entomophagus insects. In: Genetics of colonizing species, 1965.

5. Devi R, Tambe VJ, Sravankumar G, Nage SM. Larvicidal effect of some newer insecticide on Chrysoperla carnea (Stephens). Internat. J Plant Protc. 2014; 7(1):91-95.

6. El-Zahi S, El-Zahi. Selectivity of some pesticides for various stages of Chrysoperla carnea (Steph.) using different methods of exposure. Egyptian Journal of Biological Pest Control. 2012; 22(2):211-216.

7. Erkilic LB, Ygnn N. Studies on the effects of some pesticides on white peach scale (Targ-Togz) (Homoptera: Diaspidae) and its side effects on two common scale insect predators. Crop Prot. 1997; 16:89-75.
8. Garland JA. Identification of Chrysopidae in Canada with bio-nomic notes (Neuroptera). Can. Entomol. 1985; 117:737-762.

9. Garzon A, Medina P, Amor F, Vinuela E, Budia F. Toxicity and sublethal effects of six insecticides to last instar larvae and adults of the biocontrol agents Chrysoperla carnea (Stephens) (Neuroptera: Chrysopidae) and Adalia bipunctata (L.) (Coleoptera: Coccinellidae). J. Chemosphere. 2015; 132:87-93.

10. Gomez KA, Gomez AA. Statistical procedure for agricultural research. 2nd ed. New York. John Wiley and Sons, 1984, 680.

11. Govindaraj RS, Kuttalam, YS, Edward JT. Bioassay of synthetic pyrethroid insecticides on Chrysoperla carnea (Stephens) (Chrysopidae: Neuroptera). Journal article: Lifesciences Leaflets. 2015; 66:55-60.

12. Hassell MP. The Dynamics of Arthropod predator-prey system. Princeton University press, Princeton, NJ, USA, 1978.

13. Huggi A , Mallapur CP. Evaluation of toxicity of insecticides on Chrysoperla zastrowi sillemi (EsbenPeterson) and Trichogramma chilonis (Ishii) under laboratory conditions. J Farm Sci. 2016; 29(3):352-354.

14. Hussain D, Ali A, Tariq R, Mushtaq-ul-Hassan M, Saleem M. Comparative toxicity of some new chemistry insecticide on Chrysoperla carnea (stephens) under laboratory conditions. J Agric. Res, 2012, 50(4).

15. Khuram Z, Ashfaq M. Sustainable management of whitefly, Bemisia tabaci (genn.) (homoptera: aleyrodidae) in transgenic cotton. Ph.d (thesis), Department of agri. Entomology.Faculty of agriculture, Faisalabad Pakistan, 2011.

16. Lingren PD, Ridgway RL, Jones SL. Consumption by several common arthropod predators of eggs and larvae of two Heliothis species that attack cotton. Ann. Entomol. Soc. Am. 1968; 61:613-617.

17. Liu TX, Chen TY. Effect of chitin synthesis inhibitor buprofezin on survival and development of immatures of Chrysoperla rufilabris (Neuroptera: Chrysopidae). Journal of Economic Entomology. 2000; 93(2):234-239.

18. Meghannavar P, Kambrekar DN. Toxicity of different doses of insecticides to Chrysoperla zastrowi sillemi under laboratory conditions. Journal of Farm Sciences. 2016; 29(3):355-359

19. Michaud JP. Evaluation of green lacewings, Chrysoperla plorabunda (fitch) (Neuroptera) augmentative release against Toxoptera citricida (Homoptera: Aphididae) in citrus. J App. Entomol. 2001; 22:383-388.

20. Moens J, Clercq PD, Tirry L, Side Effects of Pesticides on the Larvae of the Hoverûyepisyrphus balteatus in the laboratory, Phytoparasitica. 2011; 39:1-9.

21. Nasreen A, Mustafa G, Ashfaq M. Mortality of Chrysoperla carnea (Stephens) (Neuroptera: Chrysopidae) after exposure to some insecticides; laboratory studies. South pacific studies. 2005; 26(1):1-6.

22. Nordlund DA, Vecek DC, Ferro DN. Predation of Colarado potato beetle (Coleoptera: Chrysomelidae) eggs \& larvae by Chrysoperla rufilabris (Neuroptera: Chrysopidae) larvae in the laboratory \& field cages. J Entomol. Sci. 1991; 26:443-449.

23. Omar BA, El-Khoulyand MI, Tohamy TH. Field evaluation of certain insecticides on Pegomyamixta and related predators inhabiting sugar beet fields. Egyptian Journal of Agricultural Research. 2002; 80(3):1055-1063. 
24. Pedigo LP. Common Green lacewing in Entomology and Pest Management $4^{\text {th }}$ Edition Prentice Hal, New Delhi, 1989, 317-318.

25. Prema MS. Evaluating the Biosafety of Newer and Conventional Insecticides against Parasitoids, Predators and Pollinators Prevailing in Agricultural Ecosystem: To achieve Agricultural Sustainability in Future. Res. J Recent Sci. 2016; 5(8):11-15.

26. Singh S. Impact of new chemistry on biocontrol Agents of major crop pests Int. J Agric.Sc \& Vet. Med. 2015; 3(1):15-33.

27. Shah V, Paul B, Guru G, Pandi P, Shankarganesh K. Relative toxicity of insecticides on larval stages of green lacewing, Chrysoperla sp. (carnea-group) (Chrysopidae: neuroptera). Indian Journal of Entomology. 2012; 74(4):394-397.

28. Silva BKA, Godoy MSD, Lima AGD, Oliveira AKSD, Pastori PL. Toxicity of insecticides used in muskmelon on first-instar larvae of Chrysoperla genanigra freitas (neuroptera: chrysopidae). Rev. Caatinga, Mossoró. 2016; 30(3):662- 669.

29. Sparks TC. Insecticide discovery: An evaluation and analysis. Pestic. Biochem. Physiol. 2013; 107:8-17.

30. Sterk G, Hassan SA, Baillod MF, Bakker F, Bigler S, Blumel $\mathrm{H}$ et al. Results of the seventh joint pesticide testing programme carried out by the IOBC/ WPRSWorking Group 'Pesticides and Beneficial Organisms'. BioControl. 1999; 44:99-117.

31. Ullah Z, Sabri MA, Ahmad S, Bilal H, Hussain D, Mughal TK et al. In vitro study of comparative toxicity of different insecticides against Chrysoperla carnea (Stephens) (Neuroptera: Chrysopidae). Journal of Entomology and Zoology Studies. 2017; 5(3):697-702. 